\title{
Familial omphalocele syndrome with facial dysmorphism
}

INSERM

\section{Source}

INSERM. (1999). Orphanet: an online rare disease and orphan drug data base. Familial omphalocele syndrome with facial dysmorphism. ORPHA:280403

Familial omphalocele syndrome with facial dysmorphism is a rare genetic developmental defect during embryogenesis characterized by omphalocele associated with facial dysmorphism including flat face, short, upturned nose, long and wide philtrum and flattened maxillary arch and abnormalities of hands. 